\title{
Oral and Maxillofacial - Body Connection
}

\author{
Reda A Abdel-Fattah* \\ American Board of Orofacial Pain, USA
}

Submission: February 06, 2017; Published: February 16, 2017

*Corresponding author: Reda A Abdel Fattah, American Board of Orofacial Pain, American Board of Craniofacial Pain \& American Board of Craniofacial Dental Sleep Medicine, 1050 NW 15 ${ }^{\text {th }}$ Street, Suite 211A, Boca Raton, Florida 33486, USA, Tel: (561) 391-5331;

Email: info@dentalTMJpain.com

\section{Introduction}

Dentistry is the branch of medical sciences that deals with evaluation, diagnosis, prevention and/or treatment (nonsurgical, surgical or related procedures) of diseases, disorders and/ or conditions of the oral cavity, maxillofacial area and/or the adjacent and associated structures and their impact on the human body, provided by a dentist, within the scope of his/her education, training and experience, in accordance with the ethics of the profession and applicable law [1]. Therefore, health care providers must consider the significant effects of oral and maxillofacial health on the rest of the body and mind and collaborate with their dental colleagues to achieve a higher level of general health and patient's well-being.

In the last few decades, countless studies have confirmed the link between poor oral health and systemic diseases such as cardiovascular diseases; coronary heart disease and stroke, diabetes mellitus, bacterial pneumonia, rheumatoid arthritis, and even pregnancy complications. Periodontal diseases, which are chronic Gram-negative infections, represent a risk factor for atherosclerosis and thromboembolic events. The reason is that the abnormal teeth configuration host a large number of bacteria that disseminates to the blood stream shortly after certain events when oral tissues are manipulated during dental procedures. Organisms from the infected sites may reach the heart, lungs, and peripheral blood capillary system [2]. Propionibacterium acnes, Peptostreptococcus prevotii, Fusobacterium nucleatum, Prevotella intermedia, Saccharomyces cerevisiae, Actinomyces israelii, Streptococcus intermedius, and Streptococcus sanguis are examples of these disseminating organisms [3].

The dental professionals offer many procedures to eliminate these pathogens such as dental prophylaxis, periodontal scaling and root planning, gingivectomy, periodontal osseous surgical pocket reduction and endodontic extractions of necrotic or infected pulp and/or periapical tissues. In some cases, tooth extraction may be necessary to eliminate the sites that may favor harboring these bacteria.
In addition, craniofacial trained dental professionals are able to evaluate and manage many Craniofacial Pain and dysfunctions commonly referred as Temporomandibular Disorder or TMD. TMD is called "The Great Imposter" because it causes chronic recurrent headaches as well as facial and neck pain. Furthermore, TMD sufferers frequently complain of ear symptoms including ear pain, ringing, buzzing, loss of hearing or clicking or locking of the jaw which can make chewing, speaking or moving the jaw painful or difficult. Until recently these symptoms, appearing unrelated, were frequently undiagnosed or misdiagnosed as a migraine, tension headache, neuritis, neuralgia, or stress. Today, it is well recognized within the health care community that these symptoms are related to Temporomandibular Disorders [4].

Oral appliances to balance the jaw position, physical therapy to rehabilitate the craniofacial muscles including manipulative therapy, electrotherapy, and transdermal medicinal administrations as well as pharmacological therapy are among many methods that are offered by trained dental professionals. Some cases may need surgical intervention to remove the abnormal growth or correct anatomical deformity $[5,6]$.

Thirdly, abnormal maxillofacial anatomy and tongue position and size may cause snoring and obstructive sleep apnea (OSA). These abnormalities lead to narrowing of the upper airway resulting in OSA. OSA is manifested as loud snoring, excessive daytime sleepiness, high blood pressure and other cardiovascular complications, morning headaches, memory problems, feelings of depression, gastric reflux, nocturia, and impotence. OSA is the most common type of sleep-disordered breathing (SDB) and is characterized by recurrent episodes of upper airway (UA) collapse during sleep. OSA causes intermittent hypoxia/reoxygenation (IHR), an independent risk factor for cardiovascular disease [7].

Qualified dentists with training and experience in the temporomandibular joint, dental occlusion, and associated oral structures, work with physicians construct oral appliances that reposition the mandible and consequently move to tongue forward 
dilating the upper airway for better breathing during sleep. These appliances reduce the apnea/hypopnea events and improve the patient's general condition. Oral appliance therapy is an effective, non-invasive treatment. They are comfortable, easy to wear, quiet, portable, convenient for travel and easy to care for and maintain. These appliances are indicated for snoring, mild and moderate obstructive sleep apnea as well as severe obstructive sleep apnea when surgery and or use of Continues Positive Air Pressure (CPAP) is not possible as an alternative to nothing [8].

Finally, health care professionals should consider oral and dental evaluation and treatment as another source to improve health care. They should reach out and talk to their dental colleagues to reduce dental-medical healthcare gaps and share the patient's care with them to achieve a higher level of patients' care.

\section{References}

1. ADA definition of dentistry (2017) General Dentistry.

2. Kalakonda B, Koppolu P, Baroudi K, Mishra A (2016) Periodontal Systemic Connections-Novel Associations-A Review of the Evidence with Implications for Medical Practitioners. Int J Health Sci (Qassim) 10(2): 293-307.

3. Li X, Kolltveit KM, Tronstad L, Olsen I (2000) Systemic diseases caused by oral infection. Clin Microbiol Rev 13(4): 547-558.

4. Graff Radford SB, Abbott JJ (2016) Temporomandibular Disorders and Headache. Oral Maxillofac Surg Clin North Am 28(3): 335-349.

5. Paço M, Peleteiro B, Duarte J, Pinho T (2016) The Effectiveness of Physiotherapy in the Management of Temporomandibular Disorders: A Systematic Review and Meta-analysis. J Oral Facial Pain Headache 30(3): 210-220.

6. Klasser GD, Greene CS (2009) Oral appliances in the management of temporomandibular disorders. Oral Surg Oral Medicine 107(2): 212223.

7. Cowie MR (2016) Sleep apnea: State of the art. Trends Cardiovasc Med (16): 210-219.

8. Kostrzewa Janicka J, Śliwiński P, Wojda M, Rolski D, MierzwińskaNastalska E (2017) Mandibular Advancement Appliance for Obstructive Sleep Apnea Treatment. Adv Exp Med Biol 944: 63-71.

\begin{tabular}{l} 
Your next submission with Juniper Publishers \\
will reach you the below assets \\
- Quality Editorial service \\
- Swift Peer Review \\
- Reprints availability \\
- E-prints Service \\
- Manuscript Podcast for convenient understanding \\
- Global attainment for your research \\
- Manuscript accessibility in different formats \\
( Pdf, E-pub, Full Text, Audio) \\
- Unceasing customer service \\
Track the below URL for one-step submission \\
https://juniperpublishers.com/online-submission.php \\
\hline
\end{tabular}

